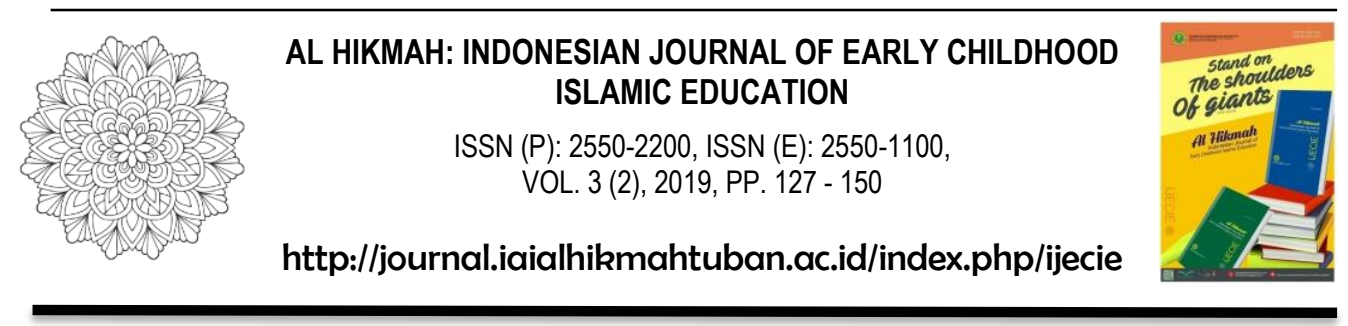

\title{
DAKON DAN LAYANG-LAYANG: REVISI PRAKTIK SEGREGASI GENDER DALAM PERMAINAN TERSTRUKTUR KELAS PRASEKOLAH
}

\author{
Laily Hidayati \\ STAI Al Hikmah Tuban \\ lailykusturayu@gmail.com
}

\begin{abstract}
Abstrak
(Pembelajaran inklusif gender pada prinsipnya adalah bagaimana menempatkan posisi antara perempuan dan laki-laki berdasarkan proporsi yang ada baik pada perempuan dan laki-laki dalam segala hal yang menyangkut realitas sosial. Khusus dalam proses pembelajaran anak usia dini, seorang guru harus mampu menempatkan posisi dimana terjadi interaksi antara laki-laki dan perempuan pada peserta didik, tidak terjadi kesenjangan dan ketimpangan dalam mengakses dan memperoleh pendidikan. Guru haruslah peka tehadap potensi-potensi terjadinya ketidakadilan atau ketimpangan gender yang muncul dalam permainanpermainan yang dilakukan olek anak didiknya. Guru harus dapat menyusun program pembelajaran sedemikian rupa sehingga celah-celah tumbuhnya ketimpangan gender dan mengakarnya kebiasaan bias gender sejak usia dini dapat diantisipasi mulai dari ketika anak berada pada jenjang prasekolah. Permasalahan gender dalam pendidikan penting untuk dituntaskan. Pemahaman gender yang baik dapat membantu warga sekolah berperan lebih baik untuk meningkatkan kualitas pendidikan, serta pada jenjang pendidikan usia dini dapat menjadi dasar-dasar pemahaman yang baik pada diri anak, tentang pola relasi sosial yang adil gender. Hal itu dapat dimulai dengan cara menciptakan pembelajaran yang mendukung perlakuan partisipatif yang sama antara siswa laki-laki dan perempuan. Penelitian ini ingin melihat praktik pembelajaran inklusif gender di lembaga pendidikan anak usia dini, yang bernuansa segregasi dan penyatuan gender berupa penyusunan program permainan terstruktur di kelas prasekolah)
\end{abstract}

Kata Kunci: gender, segregasi gender, inklusif gender, permainan terstruktur

Abstract

THIS WORK IS LICENSED CREATIVE COMMONS ATTRIBUTION-NONCOMMERCIAL 4.0 INTERNATIONAL LICENSE@ 2019 PROGRAM STUDI PENDIDIKAN ISLAM ANAK USIA DINI, STAI AL HIKMAH TUBAN, JAWA TIMUR 
[Gender inclusive learning in principle is how to position women and men based on the proportions that exist both for women and men in all matters relating to social reality. Specifically in the process of early childhood learning, a teacher must be able to place positions where there is interaction between boy and girl in students, there are no gaps in accessing and obtaining education. Teachers must be sensitive to the potential for injustice or gender inequality that appears in the games played by their students. The teacher must be able to arrange the learning program in such a way that the gaps in the growth of gender inequality and the root of the habit of gender bias from an early age can be anticipated starting from when the child is at the preschool level. Gender issues in education are important to solve. A good understanding of gender can help everyone in school play a better role in improving the quality of education, and at the level of early childhood education can be the basics of a good understanding of children, about patterns of genderequitable social relations. It can be started by creating learning that supports the same participatory treatment between boy and girl students. This study wants to see the practice of gender inclusive learning in early childhood education institutions, which nuances of gender segregation and unification in the form of structured game programmed by preschool.]

Keywords: gender, gender segregation, gender inclusive, structured play

\section{PENDAHULUAN}

Dalam satu dekade terakhir, istilah gender sudah menjadi bahan pembicaraan dan diskusi serta kajian dalam berbagai forum. Yang ringan seperti sosialisasi keluarga adil gender, yang sedang seperti porsi perempuan dalam legislative, sampai yang berat seperti Undang-undang responsif gender serta penanganan kasus-kasus kekerasan terhadap perempuan. Isu kesetaraan gender muncul dari menguatnya kesadaran publik bahwa telah terjadi ketimpangan antara laki-laki dan perempuan pada penyelanggaraan kehidupan bersama. Ketimpangan ini tidak saja ada di negara-negara berkembang, namun telah menjadi sebuah fenomena global. Salah satu riset yang menunjukkan ketimpangan yang terjadi di masyarakat Barat adalah riset yang dilakukan oleh Mino Vianello dkk. yang diterbitkan dalam buku Gender Inequality: A comparative Study of Discrimination and Participation 
yang diterbitkan tahun 1990. Dalam penelitiannya, Vianello menemukan bahwa kesenangan dan ketimpangan tersebut dibentuk oleh berbagai hal, di antaranya adalah pemahaman perbedaan sex dan nilai-nilai yang ada di dalam masyarakat yang telah lumrah dan membudaya.

Dalam kondisi saat ini masih banyak fakta interaksi sosial yang menunjukkan bahwa perbedaan jenis kelamin dapat menimbulkan perbedaan gender (gender differences), dimana kaum perempuan itu tidak rasional, emosional dan lemah lembut, sedangkan laki-laki memiliki sifat rasional, kuat dan perkasa. Gender diffrences (perbedaan gender) sebenarnya bukan suatu masalah sepanjang tidak menimbulkan gender inequalities (ketidakadilan gender). Namun yang menjadi masalah adalah ternyata gender differences tersebut telah memunculkan berbagai tindakan ketidakadilan, baik bagi bagi kaum laki-laki dan utamanya terhadap kaum perempuan. Secara biologis (kodrat) kaum perempuan dengan organ reproduksinya dapat menjalankan peran sebagai sosok yang mengandung keturunan, melahirkan dan menyusui, kemudian gender role (peran gender) sebagai perawat, pengasuh dan pendidik anak. Dengan demikian gender role dianggap tidak menimbulkan masalah dan tidak perlu dipermasalahkan dan digugat.

Di antara sekian fenomena ketimpangan atau ketidakadilan gender yang terjadi dalam lingkungan keseharian kita, salah satu oenyebabnyanya adalah pandangan terhadap laki-laki dan perempuan yang dibuat oleh masyarakat dan keluarga yang mana pandangan tersebut telah mengakar dan turun temurun dipegang sebagai tradisi yang cenderung dianggap benar dan harus dilestarikan. Pengaruh stereotip itu begitu besar dan kuat sehingga tidak mudah untuk diubah, bahkan sudah dianggap sebagai kebenaran umum. Bias genderdimulai dari keluarga, ketika orang tua mulai membeda- 
bedakan perlakuan kepada anak-anak mereka yang berjenis kelamin beda, seperti sifat yang dilekatkan, peran, kedudukan, tanggung jawab, dimana misalnya dalam hal tugas membantu orang tua di rumah, anak laki-laki mendapat porsi lebih banyak daripada anak perempuan. Pendidikan di sekolah pun demikian. Banyak diketemukan rumusan kalimat-kalimat dalam buku pembelajaran yang tidak mencerminkan kesetaraan gender. Dalam pembelajaran-pembelajaran motivasional di sekolah-sekolah misalnya, pilot selalu ditampilkan ebagai sosok laki-laki karena dianggap pekerjaan tersebut memerlukan kecakapan dan kekuatan yang dikira "hanya" dimiliki laki-laki. Bias gender di rumah maupun di lingkungan sekolah tidak hanya berdampak negatif bagi siswa atau anak perempuan tetapi juga bagi laki-laki. Anak perempuan diarahkan untuk selalu tampil cantik, lembut, penurut, dan melayani. Sementara laki-laki diarahkan untuk tampil gagah, kuat, bertanggungjawab, dan berani. Ini akan sangat berpengaruh pada peran sosial mereka di masa mendatang. Singkatnya, ada aturan-aturan tertentu yang dituntut oleh masyarakat terhadap perempuan dan laki-laki, yang sebenarnya bila dicermati -dan dikondisikan - dapat lebih saling menguntungkan antara kedua belah pihak untuk saling dapat hidup bersama dalam harmoni yang sehat dan bahagia.

Ikhtiar untuk meningkatkan kesetaraan dan keadilan gender dalam bidang pendidikan dapat dikembangkan sedini mungkin, dalam jenjang prasekolah, baik melalui pendidikan formal di sekolah maupun nonformal di rumah dengan menciptakan kondisi belajar yang menghargai kesetaraan gender serta mengkritisi bentuk permainan dan media ajar yang masih bias gender, agar nilai-nilai kesetaraan dan keadilan gender terinternalisasi sampai ahir hayat. Pendidikan kesetaraan gender juga bisa ditampilkan lewat film, video dokumenter, atau biografi yang tujuannya untuk menyadarkan 
kepada orang tua dan masyarakat bahwa stereotip gender yang berlaku di masyarakat selama ini tidak selalu bena. Misalnya, melalui tayangan biografi atau profil tokoh, dapat ditampilkan astronot wanita, ahli masak laki-laki yang sukses, tukang salon laki-laki, ahli tata rias pria, pengemudi bus wanita, atlet angkat besi wanita, panjang tebing wanita, bela diri wanita, dsb. Pada akhirnya keluarga dan masyarakat mampu mengubah pola pandang mereka selama ini terhadap masalah gender ini.

Namun meski telah hamper satu dekade pengarus-utamaan gender gencar dilakukan, tak banyak yang berubah dalam budaya masyarakat kita. Nuansa-nuansa ketimpangan gender masih tampak cukup kental. Hal tersebut disebabkan oleh telah mengakarnya bangunan budaya yang bias gender. Bangunan budaya tersebut telah tua dan mendarah daging dalam relasi sosial masyarakat kita. Maka taka da pilihan lain kecuali memulai menata kembali kesalahfahaman penempatan peran gender tersebut sejak sedini mungkin, karena dari sanalah tunas-tunas masa depan akan tumbuh membawa perubahan dan semangat baru untuk menciptakan peradaban dunia yang lebih damai, harmonis, dan bahagia. Penelitian ini ingin melihat praktik pembelajaran inklusif gender di lembaga pendidikan anak usia dini, yang bernuansa segregasi dan penyatuan gender berupa penyusunan program permainan terstruktur di kelas prasekolah.

\section{GENDER, KETIMPANGAN GENDER, KESETARAAN GENDER}

Sejak sepuluh tahun terakhir "kata "gender" telah menjadi perbendaharaan kata dalam setiap forum diskusi, demikian juga di Indonesia hampir semua uraian tentang program pengembangan masyarakat maupun pembangunan di kalangan organisasi non pemerintah memperbincangkan masalah gender. Kata gender dalam bahasa Indonesia dipinjam dari Bahasa Inggris. Untuk memahami konsep gender harus dibedakan kata gender 
dengan kata seks (jenis kelamin). Pengertian jenis kelamin merupakan pensifatan atau pembagian dua jenis kelamin manusia yang ditentukan secara biologis yang melekat pada jenis kelamin tertentu. Misalnya bahwa manusia jenis laki- laki adalah manusia yang memiliki penis, memiliki kala menjing, dan memproduksi sperma. Manusia perempuan adalah sosok lain yang memiliki alat reproduksi seperti rahim dan saluran untuk melahirkan, memproduksi telur, memiliki vagina dan mempunyai alat menyusui. Alat alat tersebut secara biologis melakat pada manusia jenis laki-laki dan perempuan selamanya. Artinya secara biologis alat-alat tersebut tidak bisa dipertukarkan dan secara permanen tidak berubah, karena semua perangkat tersebut merupakan ketentuan biologis atau yang dianugerahkan oleh Tuhan. (Fakih, 2010)

Sementara itu istilah gender menurut penjelasan pihak pemerintah, dalam hal ini Menteri Negara Pemberdayaan Perempuan Republik Indonesia adalah peran sosial yang dikonstruksikan oleh masyarakat, serta tanggungjawab dan kesempatan laki-laki dan perempuan yang diharapkan masyarakat agar peran-peran sosial tersebut dapat dilakukan oleh keduanya (laki-laki dan perempuan). Di dalam Women's Studies Encyclopedia dijelaskan bahwa gender adalah suatu konsep kultural yang berupaya membuat pembedaan dalam hal peran, perilaku, mentalitas,karakteristik emosional antara laki-laki dan perempuan yang berkembang dalam masyarakat. (Kantor Menteri Negara Pemberdayaan Perempuan Republik Indonesia, 2001)

Sedangkan konsep gender lainnya adalah suatu sifat yang melekat pada kaum laki- laki maupun perempuan yang dikonstruksi secara sosial maupun kultural. Misalnya bahwa perempuan itu dikenal lemah lembut, cantik, emosional, atau keibuan, sementara laki- laki dianggap kuat, rasional, jantan, 
perkasa. Ciri dari sifat itu sendiri merupakan sifat- sifat yang dapat dipertukarkan . artinya ada laki- laki yang emosional, lemah lembut, keibuan sementara juga ada perempuan yang kuat, rasional, perkasa. Perubahan ciri dari sifat- sifat itu dapat terjadi dari waktu ke waktu dan dari tempat ke tempat yang lain. Misalnya zaman dahulu disuatu suku tertentu perempuan lebih kuat dari laki- laki, tetapi pada zaman yang lain dan ditempat berbeda laki- laki yang lebih kuat. (Esther Kuntjara, Gender Bahasa dan Kekuasaan, (Jakarta,Libri,2012), 37)

Isu kesetaraan gender muncul dari menguatnya kesadaran publik bahwa telah terjadi ketimpangan antara laki-laki dan perempuan pada penyelanggaraan kehidupan bersama. Ketimpangan ini tidak saja ada di negara-negara berkembang, namun telah menjadi sebuah fenomena global. Salah satu riset yang menunjukkan ketimpangan yang terjadi di masyarakat Barat adalah riset yang dilakukan oleh Mino Vianello dkk. yang diterbitkan dalam buku Gender Inequality: A comparative Study of Discrimination and Participation yang diterbitkan tahun 1990. Dalam penelitiannya, Vianello menemukan bahwa kesenangan dan ketimpangan tersebut dibentuk oleh berbagai hal, di antaranya adalah pemahaman perbedaan sex dan nilai-nilai yang ada di dalam masyarakat yang telah lumrah dan membudaya. (Vianello, 1990)

Dalam kondisi saat ini masih banyak fakta interaksi sosial yang menunjukkan bahwa perbedaan jenis kelamin dapat menimbulkan perbedaan gender (gender differences), dimana kaum perempuan itu tidak rasional, emosional dan lemah lembut, sedangkan laki-laki memiliki sifat rasional, kuat dan perkasa. Gender diffrences (perbedaan gender) sebenarnya bukan suatu masalah sepanjang tidak menimbulkan gender inequalities (ketidakadilan gender). Namun yang menjadi masalah adalah ternyata 
gender differences tersebut telah memunculkan berbagai tindakan ketidakadilan, baik bagi bagi kaum laki-laki dan utamanya terhadap kaum perempuan. Secara biologis (kodrat) kaum perempuan dengan organ reproduksinya dapat menjalankan peran sebagai sosok yang mengandung keturunan, melahirkan dan menyusui, kemudian gender role (peran gender) sebagai perawat, pengasuh dan pendidik anak. Dengan demikian gender role dianggap tidak menimbulkan masalah dan tidak perlu dipermasalahkan dan digugat.

Di bawah ini beberapa isu yang berkaitan dengan ketimpangan gender, yaitu antara lain sebagai berikut: (Megawangi, 1999)

1) Marginalisasi. Timbulnya kemiskinan yang terjadi dalam masyarakat dan negara merupakan sebagai akibat dari proses marginalisasi yang menimpa kaum laki- laki dan perempuan yang disebabkan oleh berbagai kejadian. Antara lain penggusuran, bencana alam atau proses eksploitasi. Bentuk marginalisasi yang paling dominan terjadi terhadap kaum perempuan yang disebabkan oleh gender. Meskipun tidak setiap bentuk marginalisasi perempuan disebabkan oleh ketidakadilan gender, namun yang diepermaslahkan disini adalah bentuk marginalisasi yang disebabkan oleh perbedaan gender (gender differences).

2) Gender differences ini sebagai akibat dari beberapa perbedaan jenis dan bentuk, tempat dan waktu serta mekanisme dari proses marginalisasi kaum perempuan. Gender differences ini bila ditinjau dari sumbernya dapat berasal dari kbijakan pemerinah, keyakinan, tafsir agama, keyakinan tradisi, dan kebiasaan, atau bahkan asumsi ilmu pengetahuan. Misalnya program pertanian green revolution (revolusi hijau) yang hanya memfokuskan petani laki-laki sehingga secara ekonomis menyebabkan banyak perempuan desa tersingkir dan menjadi miskin. 
Hal ini disebabkan asusmsi bahwa petani itu dengan jenis kelamin lakilaki sehingga banyak petani perempuan yang tersingkir dari sawah. Kemudian adanya program kredit untuk petani yang artinya petani yang berjenis kelamin laki-laki, serta adanya pelatihan bagi petani yang hanya ditujukan bagi petani laki-laki. Hal ini mengakibatkan banyaknya kaum perempuan miskin desa termarginalisasi, yakni semakin miskin dan tersingkir karena tidak mendapatkan pekerjaaan di sawah. Ini berarti bahwa program green revolution dirancang tanpa melalui pertimbangan aspek gender. Bentuk marginalisasi terhadap kaum perempuan juga terjadi dalam rumah tangga, masyarakat atau kultur dan bahkan negara, jadi tidak hanya terjadi di tempat pekerjaan. Di dalam rumah tangga, marginalisasi terhadap perempuan sudah terjadi dalam bentuk diskriminasi atas anggota keluarga yang laki-laki dan perempuan. Timbulnya proses marginalisasi ini juga diperkuat oleh tafsir keagamaan maupun adat istiadat. Misalnya, pemberian hak waris di dalam sebagian tafsir keagamaan porsi untuk laki-laki dan perempuan berbeda, dimana pembagian hak waris untuk untuk laki-laki lebih besar dari perempuan. (Nugroho, 2008)

3) Subordinasi. Subordinasi timbul sebagai akibat pandangan gender terhadap kaum perempuan. Sikap yang menempatkan perempuan pada posisi yang tidak penting muncul dari adanya anggapan bahwa perempuan itu emosional atau irasional sehingga perempuan tidak bisa tampil memimpin merupakan bentuk dari subordinasi yang dimaksud.Proses subordinasi yang dsebabkan karena gender terjadi dalam segala macam bentuk dan mekanisme yang berbeda dari waktu ke waktu dan dari tempat ke tempat. Dalam kehidupan di masyarakat, rumah tangga, dan bernegara, banyak kebijakan yang dikeluarkan 
pemerintah yaitu jika suami akan pergi belajar (jauh dari keluarga) dapat mengambil keputusan sendiri sedangkan bagi istri harus dapat seizin suami. Dalam rumah tangga misalnya,dalam kondisi keuangan rumah tangga yang terbatas, masih sering terdengar adanya prioritas untuk bersekolah bagi laki-laki dibanding perempuan, karena ada anggapan bahwa perempuan tidak perlu sekolah tinggi-tinggi, karena pada akhirnya nanti akan masuk kedapur. Hal seperti ini sesungguhnya muncul dari kesadaran gender yang tidak adil.

4) Stereotip. Pelebelan atau penandaan negatif terhadap kelompok atau jenis kelamin tertentu, secara umum dinamakan stereotip. Akibat dari stereotip ini biasanya timbul diskriminasi dan berbagai ketidak adilan. Salah satu bentuk stereotip ini adalah yang bersumber dari pandangan gender. Banyak sekali bentuk yang terjadi di masyarakat yang dilekatkan jepada umumnya kaum perempuan sehingga berakibat menyulitkan, membatasi,memiskinkan dan merugikan kaum perempuan.bahwa laki-laki. Sebagai contoh misalnya adanya keyakinan di masyarakat bahwa laki-laki adalah pencari nafkah, maka setiap pekerjaan yang dilakukan oleh perempuan dinilai hanya sebagai tambahan saja sehingga pekerjaan perempuan boleh saja dibayar lebih rendah dibanding laki- laki. Kemudian adanya anggapan dimasyarakat bahwa perempuan bersolek biasanya dilakukan dalam rangka memancing perhatian lawan jenis, hal ini selalu dikaitksn bahkan perempuan sebagai korban yang disalahkan. Selain itu ada anggapan daari masyarakat yang melihat bahwa tugas perempuan adalah melayani suami. Stereotip seperti ini memang suatu hal yang wajar, namun beraikbat pada menomorduakan pendidikan bagi kaum perempuan.

5) Violence (kekerasan) merupakan assault (invasi) atau serangan terhadap 
fisik maupun integritas mental psikologis seseorang yang dilakukan terhadap jenis kelamin tertentu, umumnya perempuan sebagai akibat dari perbedaan gender. Bentuk dari kekerasan ini seperti pemerkosaan dan pemukulan hingga pada bentuk yang lebih halus lagi seperti sexual harrasment (pelecehan seksual) dan penciptaan ketergantungan. Violence terhadap perempuan banyak sekali terjadi karena stereotip gender. Pemerkosaan yang merupakan salah satu bentuk violence yang sering kali terjadi sebenarnya disebabkan bukan karena unsur kecantikan melainkan karena kekuasaan dan stereotip gender yang dilekatkan pada kaum perempuan. Gender violence pada dasarnya disebabkan karena ketidaksetaraan kekuatan yang ada dimasyarakat. Violence yang disebabkan oleh bias gender ini disebut genderrelate violence.

Kesetaraan gender adalah sebuah frasa (istilah) yang sering diucapkan oleh para aktivis sosial,kaum feminis,politikus bahkan hampir oleh para pejabat negara. Istilah kesetaraan gender dalam tataran praksis hampir selalu diartikan sebagai kondisi ketidaksetaraan yang dialami oleh perempuan. Maka istilah-istilah diskriminasi terhadap perempuan sperti suborninasi,penindasan,kekerasan dan semacamnya. (Megawangi, 1999). Persoalan perempuan berkaitan dengan masalah kesetaraan gender ini memang dapat mengundang rasa simpati yang cukup besar dari masyarakat luas. Hal ini terjadi karena permasalahan kesetaraan gender erat kaitannya dengan persoalan keadilan sosial dalam arti yang lebih luas, yaitu isu-isu yang yang berkisar pada masalah kesenjangan orang kaya dan miskin hingga ketimpangan ekonomi antar negara kaya dan msikin. Terwujudnya ksetaraan dan keadilan gender ditandai dengan tidak adanya diskriminasi antara perempuan dan laki-laki sehingga dengan demikian antara perempuan dan 
laki-laki memiliki akses, kesempatan berpartisipasi dan kontrol atas pembangunan serta memperoleh manfaat yang setara dan adil dari pembangunan. (Mosse, 1997)

\section{PERKEMBANGAN GENDER PADA ANAK USIA DINI}

Menurut Hurlock (1997) bahwa perkembangan anak meliputi beberapa aspek, di antaranya adalah :

1) Perkembangan fisik. Perkembangan fisik dinilai sangat penting untuk dipelajari, karena baik langsung atau tidak langsung hal ini akan mempengaruhi anak sehari- hari. Pengaruh yang terjadi secara langsung, perkembangan fisik seorang anak akan menentukan keterampilan anak dalam bergerak. Secara tidak langsung, pertumbuhan dan perkembangan fisik akan mempengaruhi cara anak memandang dirinya dan memandang orang lain. Hal ini akan tercermin dari pola penyesuaian diri anak tersebut secara umum.

2) Perkembangan motorik. Artinya perkembangan pengendalian gerakangerakan jasmani melalui kegiatan syaraf pusat, urat syaraf, dan otot yang terkoordinasi. Pengendalian tersebut berasal dari perkembangan refleksi dan kegiatan masa kecil yang ada pada waktu lahir.

3) Perkembangan bicara. Yaitu kebutuhan untuk dapat menjadi bagian dari suatu kelompok sosial. Walau dengan cara lainpun anak mungkin dapat berkomunikasi dengan anggota kelompok sosial, sebelum mereka mampu untuk berbicara dengan anggota kelompok tersebut, maka peran anak dalam kelompok tersebut akan sangat kecil.

4) Perkembangan emosi. Emosi memainkan peran yang sangat penting dalam kehidupan setiap orang, maka perlu diketahui bagaimana perkembangan dan pengaruh emosi terhadap penyesuaian diri dan sosial. 
5) Perkembangan sosial. Perkembangan sosial berarti perolehan kemampuan berperilaku yang sesuai dengan tuntutan sosial.

6) Perkembangan moral. Perkembangan moral memiliki aspek kecerdasan dan impulsif. Anak hendaknya belajar untuk dapat mengetahui mana saja yang benar atau salah. Dalam mempelajari sikap moral, terdapat empat pokok utama, yaitu : (1) mempelajari apa yang diharapkan kelompok sosial, (2) mengembangkan hati nurani, (3) belajar mengalamai perasaan bersalah dan malu bila perilaku tidak sesuai dengan norma yang berlaku, dan (4) mempunyai kesempatan untuk dapat berinteraksi sosial untuk belajar tentang apa yang diharapkan masyarakat.

7) Perkembangan peran jenis kelamin. Saat belajar berperan sesuai dengan jenis kelamin merupakan bagian yang normal dari suatu proses pertumbuhan dan perkembangan seseorang, sehingga tidak ada seorangpun yang menganggapnya sebagai suatu masalah.

Ada dua tren penting dalam perkembangan gender pada anak usia dini, yaitu:

1) Permainan dan Aktivitas. Ruble and Ruble (Desmita, 2005) mengatakan bahwa perkembangan gender pada anak usia dini dapat dilihat dari berbagai permainan dan aktivitas yang dilakukannya. Sejalan dengan pendapat tersebut, Maccoby and Jacklin (Desmita, 2005) menerangkan bahwa anak-anak yang masih kecil cenderung memperkuat stereotip gender dengan memilih mainan dan aktivitas yang dihubungkan dengan jenis kelaminnya.

2) Kualitas Personal. Santrock (1995) menyebutkan bahwa baru-baru ini telah ditemukan suatu teori yang menjelaskan tentang pemahaman anak mengenai gender, yaitu teori skema gender. Teori ini menyebutkan 
tentang cara mengorganisir dunia dalam sudut pandang laki-laki dan perempuan.

Selain itu, ada pula pandangan mengenai perkembangan gender yang dikemukakan oleh Papalia, dkk (2001), yaitu :

1) Pendekatan Biologis. Sirkulasi hormone di dalam aliran darah semenjak waktu lahir dapat berpengaruh pada perkembangan otak dan perbedaan gender.

2) Pendekatan Psikoanalisis. Freud menga- takan bahwa pengenalan merupan sesuatu yang penting pada perkemba- ngan kepribadian pada usia dini.

3) Pendekatan Kognitif. Kohlberg menegaskan bahwa anak-anak mempertunjukkan kelaminnya. Mereka mengelompokkan diri mereka dan orang lain menjadi laki-laki tau perempuan dan juga mengatur dan mengelompokkan perilaku di sekitarnya yang dilakukannya melalui identitas gender, kestabilan gender, dan ketetapan gender.

4) Pendekatan Sosial. Albert Bandura mengungkapkan bahwa perkembangan gender pada anak usia dini dipengaruhi oleh tiga faktor, yaitu : (1) pengaruh orang tua, (2) pengaruh teman sebaya, dan (3) pengaruh kebudayaan.

\section{PEMBELAJARAN INKLUSIF GENDER DI KELAS PRASEKOLAH}

Pembelajaran inklusif gender pada prinsipnya adalah bagaimana menempatkan posisi antara perempuan dan laki-laki berdasarkan proporsi yang ada baik pada perempuan dan laki-laki dalam segala hal yang menyangkut realitas sosial. Khusus dalam proses pembelajaran anak usia dini, seorang guru harus mampu menempatkan posisi dimana terjadi interaksi antara laki-laki dan perempuan pada peserta didik, tidak terjadi kesenjangan dan ketimpangan dalam mengakses dan memperoleh 
pendidikan. Guru haruslah peka tehadap potensi-potensi terjadinya ketidakadilan atau ketimpangan gender yang muncul dalam permainanpermainan yang dilakukan olek anak didiknya. Guru harus dapat menyusun program pembelajaran sedemikian rupa sehingga celah-celah tumbuhnya ketimpangan gender dan mengakarnya kebiasaan bias gender sejak usia dini dapat diantisipasi mulai dari ketika anak berada pada jenjang prasekolah.

Dalam kurikulum yang digunakan sebagai acuan praktik pengajaran dan pembelajaran sehari-hari di sekolah, misi pendidikan inklusif gender tampak dalam penyusunan turunan visi misi dan tujuan satuan pendidikan ke dalam bentuk program-program aplikatif yang tersebar dalam program tahunan sekolah. Program-program tersebut disusun sedemikian rupa sebagai langkah inovatif sekolah guna menegakkan kembali tonggak keadilan gender yang selama ini bengkok oleh sejarah tradisi nenek moyang. Sebagaimana diketahui terdapat banyak metode pembelajaran yang khas dan efektif digunakan dalam pembelajaran anak usia dini, yaitu antara lain metode bermain peran, metode bernyanyi dan bermain musik, metode mendongeng atau bercerita, metode bermain, serta metode karyawisata. Dalam penelitian ini, metode bermain akan menjadi asahan pisau analisis sebagai penampang munculnya kecenderungan ketimpangan atau keadilan gender pada permainan anak prasekolah. Metode bermain terstruktur akan digunakan untuk melihat indicator-indikator gender dalam interaksi sosial anak usia dini dalam sebuah permainan.

\section{SEGREGASI GENDER DALAM PERMAINAN TERSTRUKTUR ANAK PRASEKOLAH}

Segregasi gender adalah upaya memisahkan kelompok tertentu berdasarkan jenis kelamin, dalam hal ini kelompok permainan terstruktur. Segregasi gender dalam dunia pendidikan memunculkan bipolaritas 
pendapat, yaitu pertama, kelompok yang mendukung dan kedua, kelompok yang tidak mendukung terhadap penerapannya. Untuk kelompok yang mendukung beralasan bahwa setiap peserta didik mempunyai cara belajar yang berbeda berdasarkan kondisi alamiah mereka. Sedangkan bagi kelompok yang tidak mendukung mempunyai alasan bahwa sistem ini disinyalir akan menimbulkan hubungan yang kaku dan tidak alami antara laki-laki dan perempuan. Segregasi gender dalam pendidikan kemungkinan akan menciptakan kehidupan sosial yang bias gender jika sistem atau kebijakan yang diterapkan serta perlakuan yang diterima berbeda antara lakilaki dan perempuan. Serta, adanya perbedaan perlakuan tersebut dapat mematikan kreatifitas khususnya peserta didik perempuan, dimana laki-laki dianggap sebagai makhluk maskulin yang selalu mendominasi, yang ini akan menimbulkan ketidaksetaraan dalam dunia pendidikan. Tulisan ini mengkaji revisi praktik segregasi gender dalam pembelajara anak usia dini, dengan misi menyiapkan generasi milenial agar sejak dini memiliki kepekaan terhadap keadilan dan kesetaraan gender.

Terdapat empat indikator kesetaraan gender yang dapat digunakan sebagai piasau analisis ksetaraan atau ketimpangan gender dalam relasi sosial, yaitu sebagai berikut:

1) Akses. Yang dimaksud dengan aspek akses adalah peluang atau kesempatan dalam memperoleh atau menggunakan sumber daya tertentu. Mempertimbangkan bagaimana memperoleh akses yang adil dan setara antara anak perempuan dan laki-laki terhadap sumberdaya yang akan dibuat.

2) Partisipasi. Aspek partisipasi merupakan keikutsertaan atau partisipasi seseorang atau kelompok dalam kegiatan dan atau dalam pengambilan keputusan. Semua orang dalam lingkungan sosialnya dapat mengambil 
peran apapun tanpa mendapat stereotip kepantasan atau ketidakpantasan karena jenis kelaminnya.

3) Kontrol. Kontrol adalah penguasaan atau wewenang atau kekuatan untuk mengambil keputusan dalam masalah-masalah yang membutukan pemecahan, tanpa ada dominasi jenis kelamin tertentu di dalamnya.

4) Manfaat. Manfaat adalah kegunaan yang dapat dinikmati secara optimal oleh semua orang dalam lingkungan sosial, tanpa membedakan jenis kelaminnya.

Keempat indikator gender di atas dapat digunakan untuk menganalisis efektivitas program pembelajaran, dalam hal ini jenis-jenis permainan terstruktur yang bertujuan untuk meletakkan dasar-dasar budaya adil gender sejak usia dini. Permainan terstruktur adalah permainan yang dilakukan dengan mengatur lingkungan atau obyek yang dapat mendorong anak mendapatkan pengalaman baru. Orang dewasa dapat berperan sebagai teman bermain, menggali pendapat anak, memberikan arahan, dan mendorong eksplorasi lebih lanjut. Dalam permainan terstruktur, orang dewasa menentukan tujuan, aturan, instruksi, tempat, dan waktu permainan dilakukan. (White, 2012).

Secara lengkap, analisis indikator adil gender dalam program pembelajaran inklusif tersebut dapat dilihat dalam table berikut: 
Tabel 1. Indikator Aspek Internalisasi Gender INDIKATOR ASPEK INTERNALISASI GENDER DALAM PEMBELAJARAN

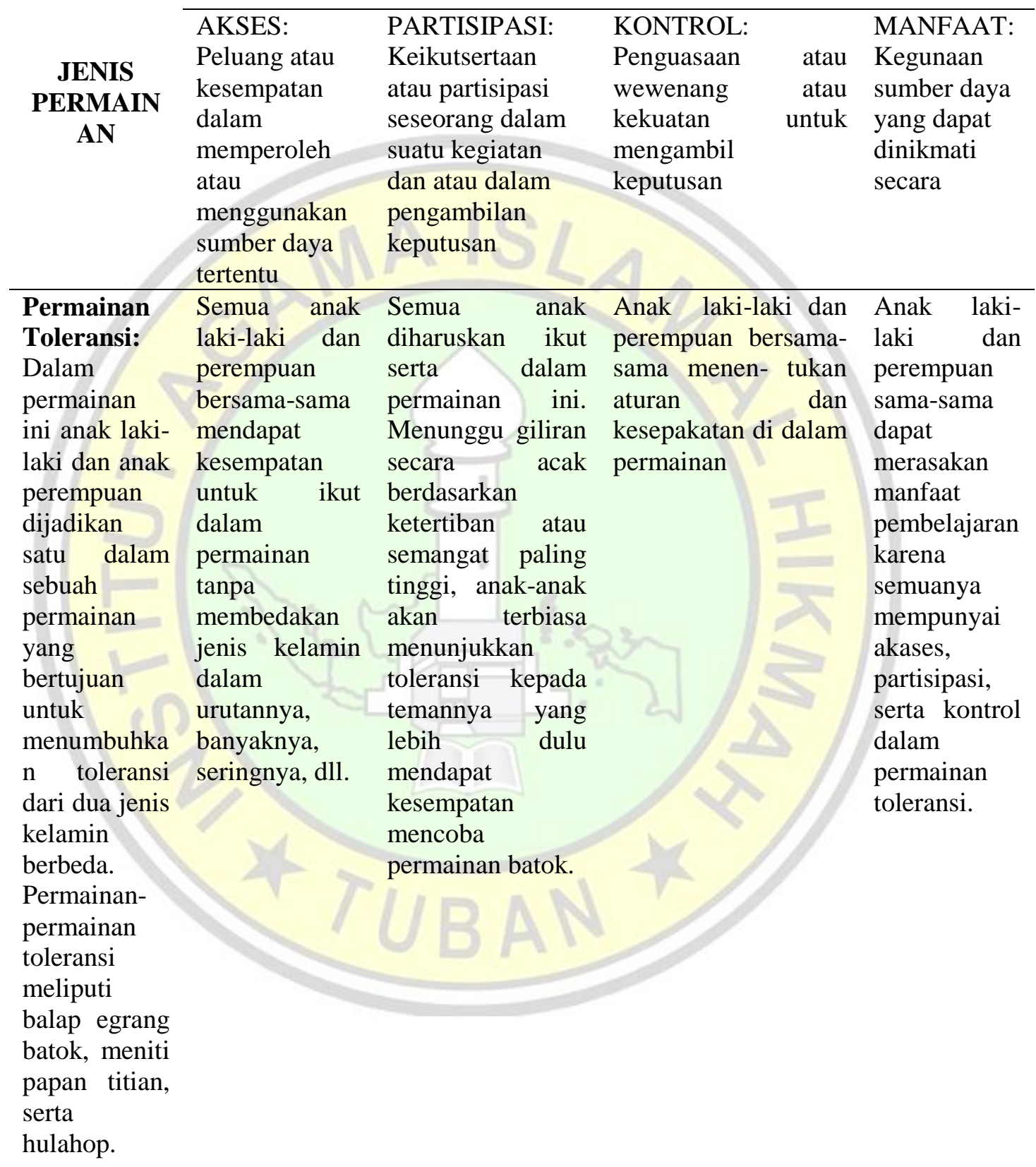

\begin{tabular}{llrllllr}
\hline Permainan & Semua & anak & Anak laki-laki & Anak laki-laki dan & Anak & laki- \\
Kerjasama: & laki-laki & dan & dan perempuan & perempuan dapat & laki & $\begin{array}{r}\text { dan } \\
\hline\end{array}$
\end{tabular}


Laily Hidayati (Dakon dan Layang-Layang)

\begin{tabular}{|c|c|c|c|c|}
\hline $\begin{array}{l}\text { Dalam } \\
\text { permainan } \\
\text { ini anak laki- } \\
\text { laki dan anak } \\
\text { perempuan } \\
\text { dijadikan } \\
\text { satu dalam } \\
\text { sebuah } \\
\text { permainan } \\
\text { yang } \\
\text { bertujuan } \\
\text { untuk } \\
\text { menumbuhka } \\
\text { n kerjasama } \\
\text { antara } \\
\text { kelompok- } \\
\text { kelompok } \\
\text { acak jenis } \\
\text { kelamin. } \\
\text { Permainan } \\
\text { jenis ini } \\
\text { meliputi } \\
\text { permainan } \\
\text { estafet } \\
\text { hulahop, } \\
\text { egrang } \\
\text { kaki, serta } \\
\text { lompat tali } \\
\text { karet. }\end{array}$ & $\begin{array}{l}\text { perempuan } \\
\text { bersama-sama } \\
\text { mendapat } \\
\text { kesempatan } \\
\text { untuk ikut } \\
\text { dalam } \\
\text { permainan } \\
\text { tanpa } \\
\text { membedakan } \\
\text { jenis kelamin } \\
\text { dalam } \\
\text { urutannya, }\end{array}$ & $\begin{array}{l}\text { mampu } \\
\text { mengutarakan } \\
\text { pendapat dan } \\
\text { argumentasinya } \\
\text { tentang } \\
\text { permainan }\end{array}$ & $\begin{array}{l}\text { memecahkan } \\
\text { masalah secara } \\
\text { bersama-sama }\end{array}$ & $\begin{array}{l}\text { perempuan } \\
\text { sama-sama } \\
\text { dapat } \\
\text { merasakan } \\
\text { manfaat } \\
\text { pembelajaran } \\
\text { karena } \\
\text { semuanya } \\
\text { dapat masuk } \\
\text { ke dalam } \\
\text { kelompok } \\
\text { serta dapat } \\
\text { menampilkan } \\
\text { perannya } \\
\text { dalam bentuk } \\
\text { kerjasama. }\end{array}$ \\
\hline $\begin{array}{l}\text { Permainan } \\
\text { Apresiasi } \\
\text { Dalam } \\
\text { permainan } \\
\text { ini anak laki- } \\
\text { laki dan anak } \\
\text { perempuan } \\
\text { dijadikan } \\
\text { satu dalam } \\
\text { sebuah } \\
\text { permainan } \\
\text { yang } \\
\text { bertujuan } \\
\text { untuk }\end{array}$ & $\begin{array}{l}\text { Semua anak } \\
\text { laki-laki dan } \\
\text { perempuan } \\
\text { bersama-sama } \\
\text { mendapat } \\
\text { kesempatan } \\
\text { untuk ikut } \\
\text { dalam } \\
\text { permainan } \\
\text { tanpa } \\
\text { membedakan } \\
\text { jenis kelamin } \\
\text { dalam } \\
\text { urutannya, }\end{array}$ & $\begin{array}{l}\text { Anak laki-laki } \\
\text { dan perempuan } \\
\text { berpartisipasi } \\
\text { dalam } \\
\text { menyampaikan } \\
\text { ide, gagasan, } \\
\text { saran, serta } \\
\text { masukan untuk } \\
\text { temannya. }\end{array}$ & $\begin{array}{l}\text { Anak perempuan dan } \\
\text { laki-laki keduanya } \\
\text { memperoleh } \\
\text { kesempatan untuk } \\
\text { bergantian menjadi } \\
\text { juri pentas, sehingga } \\
\text { punya kesempatan } \\
\text { untuk berwenang } \\
\text { menentukan pilihan } \\
\text { dan membuat } \\
\text { keputusan bersama. }\end{array}$ & $\begin{array}{l}\text { Anak laki- } \\
\text { laki dan } \\
\text { perempuan } \\
\text { sama-sama } \\
\text { dapat } \\
\text { merasakan } \\
\text { manfaat } \\
\text { pembelajaran } \\
\text { karena } \\
\text { semuanya } \\
\text { memperoleh } \\
\text { kesempatan } \\
\text { belajar dalam } \\
\text { lingkungan } \\
\end{array}$ \\
\hline
\end{tabular}




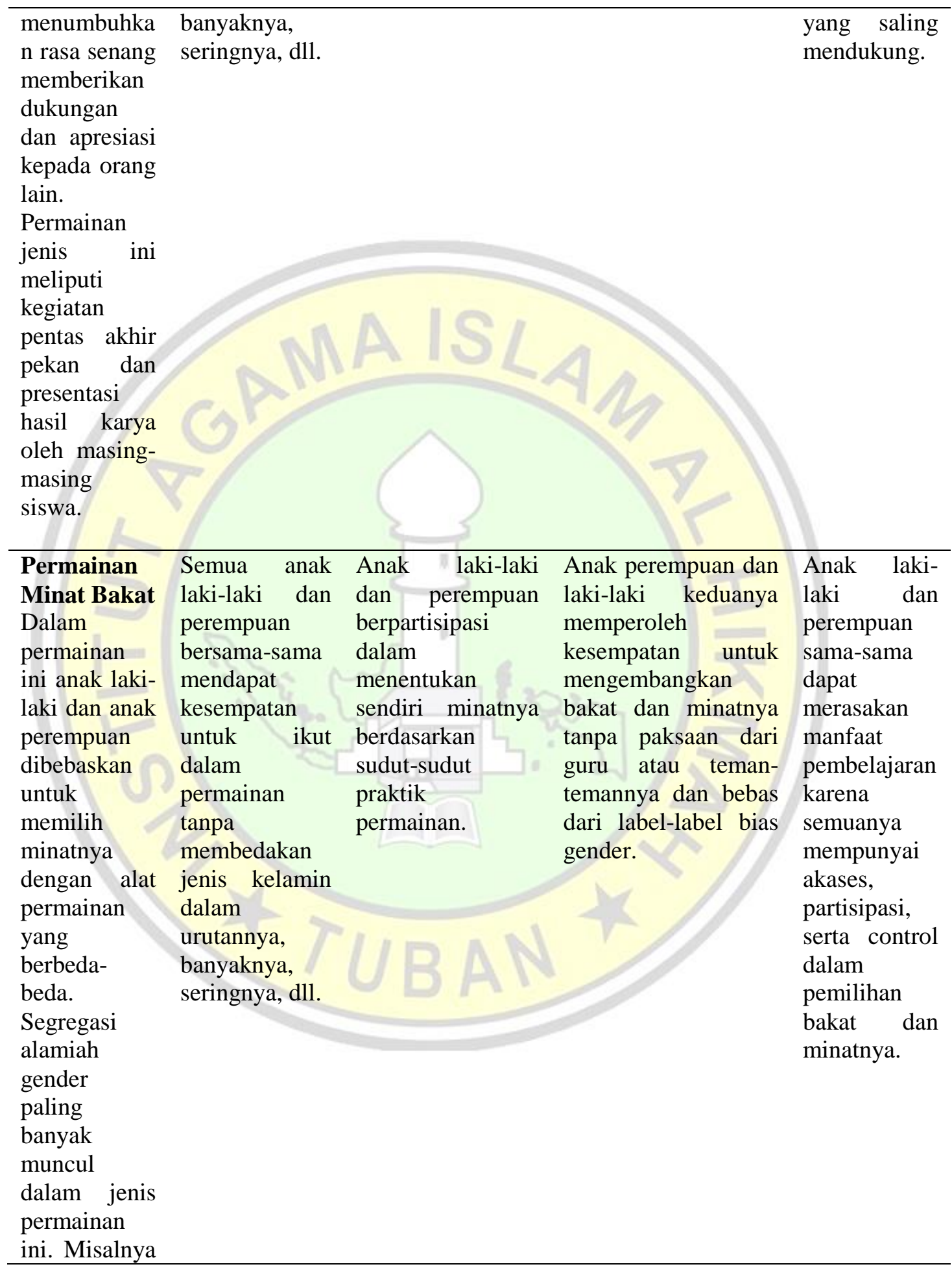




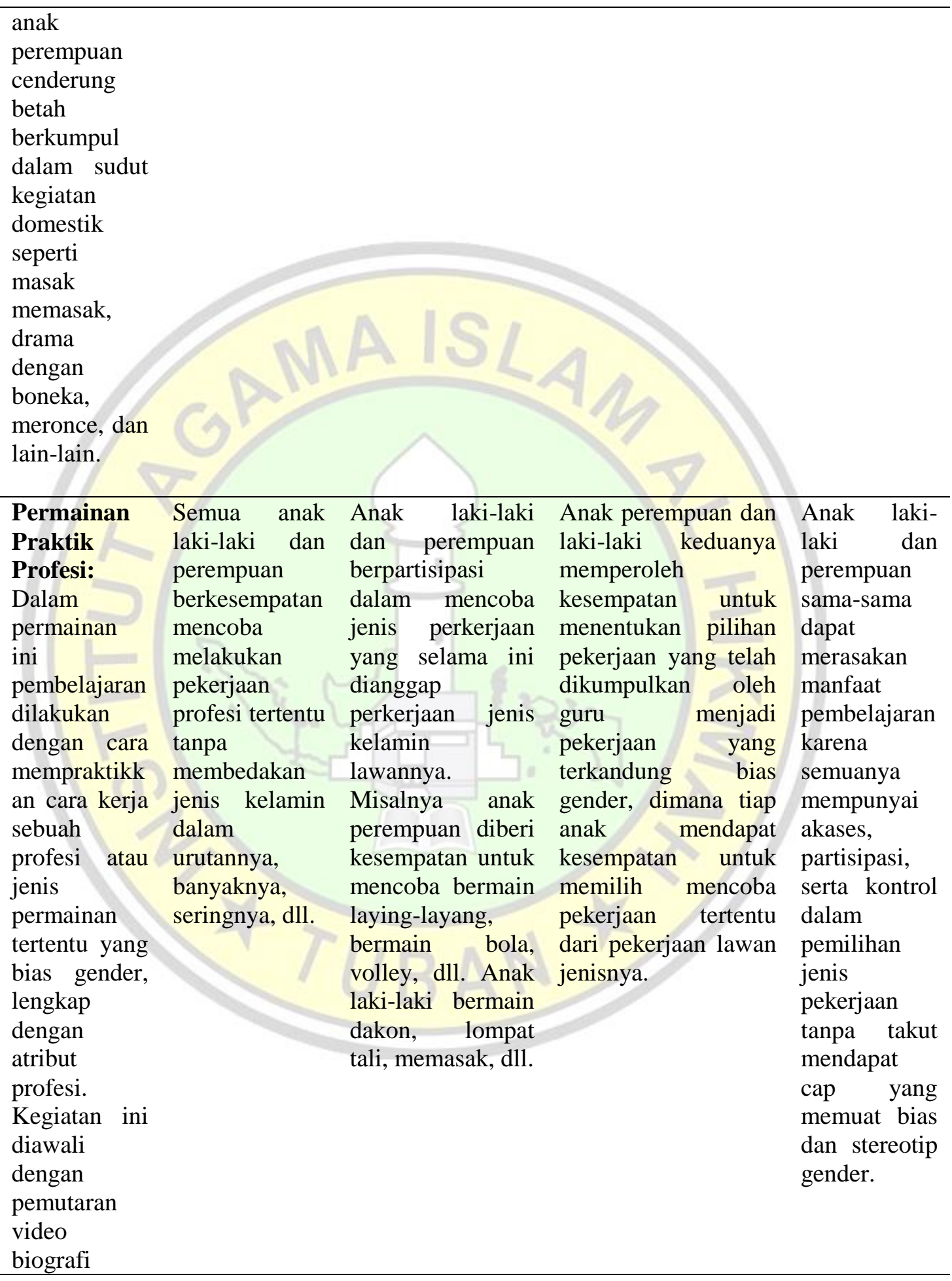


tokoh-tokoh profesi

tertentu yang

menunjukkan

keseteraan

gender.

\section{PENUTUP}

\section{Simpulan}

Permasalahan gender dalam pendidikan penting untuk dituntaskan. Pemahaman gender yang baik dapat membantu warga sekolah termasuk orang tua dan masyarakat stakeholder berperan lebih baik untuk meningkatkan kualitas pendidikan, serta pada jenjang pendidikan usia dini dapat menjadi dasar-dasar pemahaman yang baik pada diri anak, tentang pola relasi sosial yang adil gender. Hal itu dapat dimulai dengan cara menciptakan pembelajaran yang mendukung perlakuan partisipatif yang sama antara siswa laki-laki dan perempuan. Dalam pelaksanaan permainan terstruktur, tiap indikator aspek inklusif gender dapat masuk ke dalam semua jenis permainan. Guru bertugas memastikan kesemua aspek terlampaui oleh tiap anak tanpa membedakan jenis kelamin. Dalam permainan praktik profesi, guru agak membuat sedikit perbedaan aturan main yang segregatif gender, yaitu dengan cara menunjuk anak laki-laki untuk mencoba jenis pekerjaan yang dalam masyarakat telah dianggap sebagai pekerjaaan perempuan. Misalnya memasak, mencuci baju, menyetrika, menggendong adik bayi, dan lain-lain. Sebaliknya untuk anak perempuan, guru menunjuk untuk mencoba melakukan pekerjaan yang terlanjur dianggap sebagai pekerjaan laki-laki dalam masyarakat, misalnya mencangkul, menyetir kendaraan, menjadi presiden, pilot, tentara, dan lain sebagainya. Variasi permainan diatur sedemikian rupa hingga semua aspek indicator gender 
terlampaui, dan semua anak mendapatkan kesempatan belajar yang sama. Dengan cara ini, diaharapkan anak usia dini telah memiliki kepekaan terhadap kesetaraan gender dan ketimpangan gender, sehingga mereka dapat membawanya hingga usia dewasa, ke dalam pemahaman yang tinggi terhadap perbedaan, penerimaan yang tulus terhadap kekurangan, sehingga semua orang dapat hidup dalam harmoni kehidupan yang indah dan bahagia.

\section{DAFTAR PUSTAKA}

Asti Nur Hadianti. Pendidikan Gender Pada Anak Usia Dini. Fakultas Keguruan dan Ilmu Pendidikan Univ. Muh. Magelang. Edukasi. Jurnal Penelitian \& Artikel Pendidikan.

Carolyn Pope Edwards Lisa Knoche Asiye Kumru. Play Patterns and

Gender. Published in Encyclopedia of Women and Gender, Judith

Worrell, Editor-in-Chief (San Diego: Academic Press, 2001), Volume

2, pp. 809-815. Copyright (C 2001 Academic Press. Used by permission.

Desmita, (2005), Psikologi Perkembangan. Jakarta: PT. Remaja Rosdakarya. Fakih, Mansour. (2010). Analisis Gender dan Transformasi/Sosial. Yogyakarta: Pustaka Belajar.

Hurlock, Elizabeth B. (1997) Psikologi Perkembangan Suatu Pendekatan

Rentang Kehidupan. Edisi kelima. Jakarta: Erlangga.

Kantor Menteri Negara Pemberdayaan Perempuan Republik Indonesia, (2001). Bahan Informasi Gender-Modul 1. Jakarta.

Megawangi, Ratna. (1999). Membiarkan Berbeda Sudut Pandang Baru Tentang Relasi Gender. Jakarta: Mizan.

Mosse, Julia Cleves (2007) Gender dan Pembangunan. Yogyakarta: Pustaka Belajar. 
Nugroho, Riant (2008). Gender dan Administrasi Publik. Pustaka Belajar. Yogyakarta

Nur Iftitahul Husniyah. Pendidikan Inklusif Gender. Jurnal AKADEMIKA, Volume 8, Nomor 1, Juni 2014.

Papalia, D. E., Old, S. W., Feldman, \& R. D. (2001). Perkembangan

Manusia. Jakarta: Salemba Humanika.

Santrock, John. (1995). Life Span Development: edisi kelima. Jakarta:

Erlangga.

Vianello, Mino et.al, )1990) Gender Inequality: A Comparative Study of

Discrimination and Participation, London: Sage Publication.

White, R. E. (2012). The Power of Play: A Research Summary on Play and

Learning. St. Paul: Minnesota Children's Museum. 